\title{
Membangun Sistem Pendukung Keputusan Untuk Menentukan Dosen Berprestasi Di Prodi Informatika Fakultas Ilmu Komputer Universitas Dehasen Bengkulu
}

\author{
Arius Satoni Kurniawansyah ${ }^{1}$, Jusuf Wahyudi ${ }^{2}$, Rina Julita ${ }^{3}$ \\ 1,2,3 Dosen Tetap Program Studi Teknik Informatika, Fakultas Ilmu Komputer Universitas Dehasen Bengkulu \\ Alamat (Telp. (0736) 22027, 26957 Fax. (0736) 341139; e-mail: ariussatoni@unived.ac.id, ir.jusuf.wahyudi@gmail.com
}

\begin{abstract}
Lecturers Are A Vital Resource In A University, Because Lecturers Play Many Roles In Every Activity Of A University. Outstanding Lecturers Can Certainly Encourage Progress For A University In Particular And For A Nation In General. The Selection Of High-Achieving Lecturers At The National Level Has Been Held Since 2004. Since 2009 His Election Has Included Polytechnic Higher Education As A Form Of Appreciation For Vocational Education. Besides That, Based On The Evaluation Of The Results Of The National Achievement Lecturers Since 2004 Where The Winners Were Always From The Science Technology Field, It Was Deemed Necessary To Emerge Winners In The Field Of Social Humanities, So That The Winners From Two Fields, Namely, Science And Social Sciences Humanities, Will Be Selected. . This Study Used Descriptive Qualitative Method. The Reason For Selecting Qualitative Descriptive, Because This Research Aims To Dig Deeper About How To Determine The Lecturer Achievement. The General Objective of This Study Is To Make A Decision Support System To Determine Outstanding Lecturers In The Department Of Information Engineering, Faculty of Computer Science, Dehasen University, Bengkulu. The Results Of This Study Can Help The Study Program In Determining Lecturers With Achievement In The Department Of Information Engineering, Faculty Of Computer Science, Dehasen University, Bengkulu With A Decision Support System.

Keywords: Decision Support System, Achieving Lecturers
\end{abstract}

Intisari-Dosen Merupakan Sumber Daya Yang Sangat Vital Dalam Sebuah Perguruan Tinggi, Karena Dosen Banyak Berperan Di Dalam Setiap Aktivitas Sebuah Perguruan Tinggi. Dosen Berprestasi Tentu Dapat Mendorong Kemajuan Bagi Suatu Perguruan Tinggi Pada Khususnya Dan Bagi Suatu Bangsa Pada Umumnya. Pemilihan Dosen Berprestasi Tingkat Nasional Telah Diselenggarakan Sejak Tahun 2004. Sejak Tahun 2009 Pemilihannya Mengikutsertakan Pendidikan Tinggi Politeknik Sebagai Bentuk Apresiasi Terhadap Pendidikan Vokasi. Disamping Itu Bedasarkan Evaluasi Hasil Pemilihan Dosen Berprestasi Nasional Sejak Tahun 2004 Dimana Pemenangnya Selalu Dari Bidang Sains Teknologi, Maka Dipandang Perlu Untuk Memunculkan Pemenang Pada Bidang Bidang Sosial Humaniora, Sehingga Mulai Tahun 2017 Akan Dipilih Pemenang Dari Dua Bidang Yaitu, Bidang Sains Teknologi Dan Sosial Humaniora. Penelitian Ini Menggunakan Metode Deskriptif Kualitatif. Alasan Pemilihan Deskriptif Kualitatif, Karena Penelitian Ini Bertujuan Untuk Menggali Lebih Dalam Tentang Bagaimana Cara Menentukan Dosen Berprestasi. Tujuan Umum Penelitian Ini Adalah Membuat Sistem Pendukung Keputusan Untuk Menentukan Dosen Berprestasi Di Prodi Informatika Fakultas Ilmu Komputer Universitas Dehasen Bengkulu. Hasil Penelitian Ini Dapat Membantu Pihak Program Studi Dalam Menentukan Dosen Berprestasi Di Prodi Informatika Fakultas Ilmu Komputer Universitas Dehasen Bengkulu Dengan Sebuah Sistem Pendukung Keputusan.

Kata Kunci: Sistem Pendukung Keputusan, Dosen Berprestasi

\section{Pendahuluan}

Pendidikan tinggi di Indonesia merupakan subsistem pendidikan Nasional yang mencakup program diploma, sarjana, magister, spesialis dan doktor yang diselenggarakan oleh Perguruan Tinggi. Perguruan Tinggi berkewajiban menyelenggarakan pendidikan, penelitian dan pengabdian kepada masyarakat. Salah satu unsur dalam penyelenggaraan pendidikan tinggi adalah dosen.

Dosen merupakan tenaga akademik yang bertugas merencanakan dan melaksanakan proses pembelajaran, menilai hasil pembelajaran, melakukan pembimbingan dan pelatihan, serta melakukan penelitian serta pengabdian kepada masyarakat. Berdasarkan Undangundang Republik Indonesia No 14 Tahun 2005 tentang Guru dan Dosen, Pasal 51 Ayat (1) Butir b, bahwa dosen berhak mendapatkan promosi dan penghargaan sesuai dengan kinerja akademiknya.

Dosen merupakan sumber daya yang sangat vital dalam sebuah Perguruan Tinggi, karena dosen banyak berperan di dalam setiap aktivitas sebuah Perguruan Tinggi. Dosen berprestasi tentu dapat mendorong kemajuan bagi suatu Perguruan Tinggi pada khususnya dan bagi suatu Bangsa pada umumnya. Pemilihan dosen berprestasi tingkat Nasional telah diselenggarakan sejak tahun 2004. Sejak tahun 2009 pemilihannya mengikutsertakan pendidikan tinggi politeknik sebagai bentuk apresiasi terhadap pendidikan vokasi. Disamping itu bedasarkan evaluasi hasil pemilihan dosen berprestasi nasional sejak tahun 2004 dimana pemenangnya selalu dari bidang Sains Teknologi, maka dipandang perlu untuk memunculkan pemenang pada bidang bidang Sosial Humaniora, sehingga mulai tahun 2017 akan dipilih pemenang dari dua bidang yaitu, bidang Sains Teknologi dan Sosial Humaniora. 
Universitas Dehasen Bengkulu merupakan salah satu Perguruan Tinggi Swasta di Provinsi Bengkulu yang memiliki dua Kampus yakni Kampus I dan Kampus II. Kampus I memiliki 7 Fakultas dan Kampus II memiliki 1 Fakultas yakni Fakultas Kesehatan. Universitas Dehasen Bengkulu memiliki kiprah dalam mencerdaskan Generasi Muda sebagai wujud kontribusi bagi Bangsa dan Negara. .

Sistem penghargaan terkait dengan aspirasi dan motivasi di kalangan dosen ini diharapkan menjadi salah satu cara dalam pengembangan manajemen akademik di masing-masing Perguruan Tinggi. Selain itu sistem penghargaan akan merupakan salah satu unsur penting dan memiliki peran dalam menumbuh kembangkan suasana akademik, yang pada akhirnya dapat mempercepat perkembangan masyarakat ilmiah masa kini dan masa depan sesuai dengan yang diharapkan.

Sistem penghargaan ini harus sejalan dan sesuai dengan harkat dan martabat dosen sebagai penggali dan pengembang ilmu, teknologi, dan seni serta budaya, peneliti dan pengabdi pada masyarakat. Merujuk pada pemikiran di atas, sudah selayaknya pemberian penghargaan diberikan kepada dosen yang memiliki prestasi yang dibanggakan oleh Perguruan Tingginya dalam bidang tridarma Perguruan Tinggi. Pemberian penghargaan akan mendorong dosen untuk berprestasi secara lebih produktif. Dengan demikian prestasi yang semakin produktif itu diharapkan dapat mendorong tercapainya tujuan pengembangan sistem pendidikan tinggi khususnya, dan pembangunan Nasional pada umumnya.

\section{Tinjauan Pustaka}

\section{a. Pengertian Dosen}

Menurut Undang-undang RI No. 14 tahun 2015, Dosen adalah pendidik profesional dan ilmuwan dengan tugas utama mentransformasikan, mengembangkan, dan menyebarluaskan ilmu pengetahuan, teknologi, dan seni melalui pendidikan, penelitian, dan pengabdian kepada masyarakat.

\section{b. Kedudukan Dosen}

Kedudukan dosen sebagai tenaga profesional sebagaimana dimaksud dalam Pasal 3 ayat (1) dalam (UU RI No. 14 tahun 2005) berfungsi untuk meningkatkan martabat dan peran dosen sebagai agen pembelajaran, pengembang ilmu pengetahuan, teknologi, dan seni, serta pengabdi kepada masyarakat berfungsi untuk meningkatkan mutu pendidikan nasional.

Berdasarkan Pasal 7 ayat (1) dalam (UU RI No. 14 tahun 2005), profesi guru dan profesi dosen merupakan bidang pekerjaan khusus yang dilaksanakan berdasarkan prinsip sebagai berikut: memiliki bakat, minat, panggilan jiwa, dan idealisme; memiliki komitmen untuk meningkatkan mutu pendidikan, keimanan, ketakwaan, dan akhlak mulia; memiliki kualifikasi akademik dan latar belakang pendidikan sesuai dengan bidang tugas; memiliki kompetensi yang diperlukan sesuai dengan bidang tugas; memiliki tanggung jawab atas pelaksanaan tugas keprofesionalan; memperoleh penghasilan yang ditentukan sesuai dengan prestasi kerja; memiliki kesempatan untuk mengembangkan keprofesionalan secara berkelanjutan dengan belajar sepanjang hayat; memiliki jaminan perlindungan hukum dalam melaksanakan tugas keprofesionalan; dan memiliki organisasi profesi yang mempunyai kewenangan mengatur hal-hal yang berkaitan dengan tugas keprofesionalan guru.

\section{c. Pengertian Dosen Berprestasi}

Dosen berprestasi adalah dosen yang dalam lima tahun terakhir memiliki prestasi yang sangat bermanfaat dan dapat dibanggakan Perguruan Tinggi asal, serta diakui pada tingkat nasional atau internasional. [1]

Dosen yang berminat untuk mengikuti pemilihan dosen berprestasi harus memenuhi syarat dan ketentuan yang berlaku seperti berikut :

1. Dosen tetap Perguruan Tinggi, yang bekerja penuh waktu yang berstatus sebagai dosen tetap dan memiliki NIDN pada satuan pendidikan tinggi dan diusulkan secara tertulis oleh Pimpinan Perguruan Tinggi Negeri/Koordinator Kopertis bagi Perguruan Tinggi Swasta, dilampiri Surat Keputusan

Rektor/Ketua/Direktur/ Koordinator Kopertis tentang Dosen Berprestasi;

2. Dosen yang memiliki kualifikasi akademik sekurangkurangnya magister atau setara tanpa dibatasi usia, kepangkatan dan golongan, jabatan pimpinan Perguruan Tinggi, dan jabatan fungsional akademik; 
3. Dosen yang pernah menjadi Pemenang Pertama pada tingkat Perguruan Tinggi / Kopertis dalam periode 3 (tiga) tahun sebelumnya tidak dapat diusulkan kembali.

4. Dosen yang memiliki Karya Prestasi Unggul dalam bidang Pendidikan dan Pengajaran, Penelitian, dan Pengabdian Pada Masyarakat.[3]

\section{d. Mahasiswa}

Menurut kamus besar Bahasa Indonesia (KBBI), mahasiswa adalah mereka yang sedang belajar di Perguruan Tinggi (Poerwadarmita, 2005). Mahasiswa dapat didefinisikan sebagai individu yang sedang menuntut ilmu ditingkat Perguruan Tinggi, baik negeri maupun swasta atau lembaga lain yang setingkat dengan Perguruan Tinggi. Umumnya mahasiswa berada pada tahapan remaja akhir, yaitu berusia 18-21 tahun. Mahasiswa dinilai memiliki tingkat intlektualitas yang tinggi, kecerdasan dalam berpikir dan kerencanaan dalam bertindak. Berpikir kritis dan bertindak cepat dan tepat merupakan sifat yang cenderung melekat pada diri setiap mahasiswa, yang merupakan prinsip yang saling melengkapi. Mahasiswa adalah manusia yang tercipta untuk selalu berpikir yang saling melengkapi (Siswoyo, 2007). [4]

\section{e. Pemrograman Matlab}

Matlab merupakan bahasa pemrograman yang hadir dengan fungsi dan karakteristik yang berbeda dengan bahasa pemrograman lain yang sudah ada lebih dahulu seperti Delphi, Basic maupun $\mathrm{C}++$. Matlab merupakan bahasa pemrograman level tinggi yang dikhususkan untuk kebutuhan komputasi teknis, visualisasi dan pemrograman seperti komputasi matematik, analisis data, pengembangan algoritma, simulasi dan pemodelan dan grafik-grafik perhitungan.

Matlab hadir dengan membawa warna yang berbeda. Hal ini karena matlab membawa keistimewaan dalam fungsi-fungsi matematika, fisika, statistik, dan visualisasi. Matlab dikembangkan oleh MathWorks, yang pada awalnya dibuat untuk memberikan kemudahan mengakses data matrik pada proyek LINPACK dan EISPACK. Saat ini matlab memiliki ratusan fungsi yang dapat digunakan sebagai problem solver mulai dari simple sampai masalah-masalah yang kompleks dari berbagai disiplin ilmu.

\section{f. Sistem Pendukung Keputusan}

Jenis-Jenis Keputusan Menurut Herbert A. Simon : Keputusan Terprogram, Bersifat Berulang Dan Rutin, Sedemikian Sehingga Suatu Prosedur Pasti Telah Dibuat Untuk Menanganinya.

Keputusan Tak Terprogram, Bersifat Baru, Tidak Terstruktur dan Jarang Konsekuen. Tidak ada metode yang pasti untuk menangani masalah ini.

Tahap-Tahap Pengambilan Keputusan Menurut Simon :

1. Kegiatan Intelijen, mengamati lingkungan mencari kondisi-kondisi yang perlu diperbaiki.

2. Kegiatan Merancang, menemukan, mengembangkan dan menganalisis berbagai alternatif tindakan yang mungkin.

3. Kegiatan Memilih, memilih satu rangkaian tindakan tertentu dari beberapa yang tersedia.

4. Kegiatan Menelaah, menilai pilihan-pilihan yang lalu.[5]

\section{III.METODOLOGI PENELITIAN}

\section{A. Jenis dan Rancangan Penelitian}

Penelitian ini menggunakan metode deskriptif kualitatif. Alasan pemilihan deskriptif kualitatif, karena penelitian ini bertujuan untuk menggali lebih dalam tentang bagaimana cara menentukan Dosen Berprestasi.

\section{B. Teknik Pengumpulan Data}

Teknik pengumpulan data yang digunanakan dalam penelitian ini adalah dengan menggunakan data primer dan data sekunder. Data primer diperoleh berdasarkan hasil Indepth Interview (wawancara mendalam). Data sekunder dalam penelitian ini didapatkan dari kuisioner yang diberikan ke mahasiswa Prodi Teknik Informatika Fakultas Ilmu Komputer Universitas Dehasen Bengkulu.

\section{Pelaksanaan Penelitian}

Penelitian ini dilakukan pada tanggal 20 September 2018 - 15 Desember 2018

\section{KESIMPULAN DAN SARAN}

\section{A. Pemilihan Perangkat Lunak}

Prangkat lunak yang digunakan dalam proses implementasi) adalah MATLAB 6.0 merupakan bahasa pemprograman tingkat tinggi berbasis pada matriks yang 
sering digunakan untuk teknik komputasi numerik, menyelesaikan masalah-masalah yang melibatkan operasi matematika, elemen, matrik, optimasi, aproksimasi dan lain-lain.

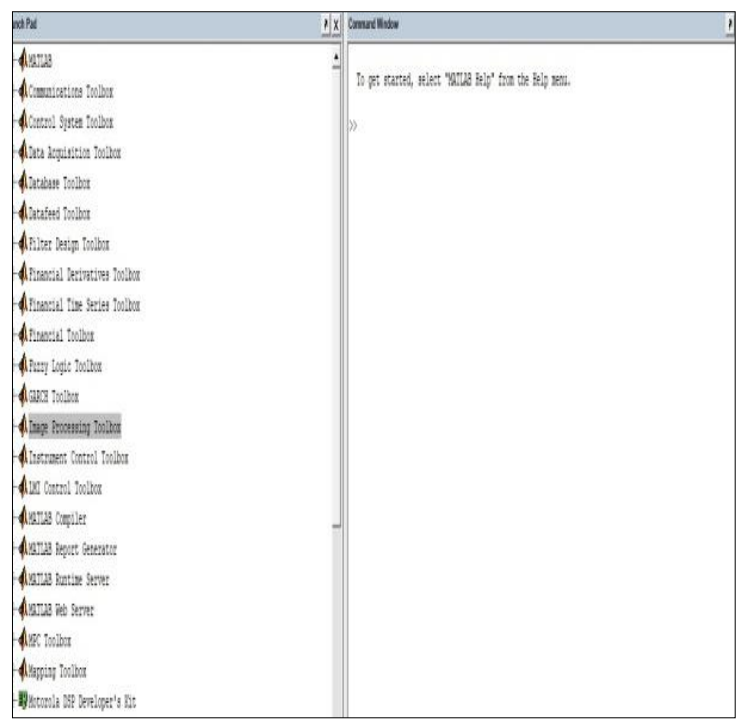

Gambar 1. Tampilan Awal Perangkat Lunak MATLAB 6.0

\section{B. Proses Pemilihan Dosen Berprestasi menggunakan Metode Fuzzy Mamdani}

Pada beranda Command Windows, kita ketikkan Fuzzy, maka akan muncul toolbox fuzzy untuk menerapkan metode Fuzzy Mamdani pada proses Pemilihan Dosen Berprestasi di Prodi Teknik Informatika Universitas Dehasen Bengkulu. Tampilannya sebagai berikut :

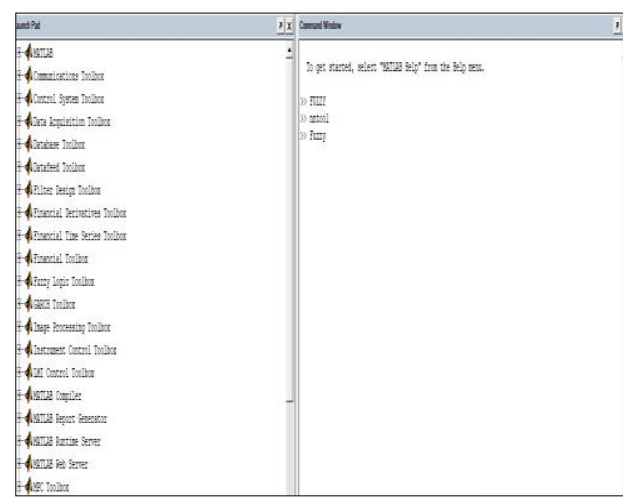

Gambar 2. Tampilan Pemanggilan Toolbox Fuzzy

\section{Proses Pembuatan Variabel Input Pendidikan dan}

\section{Pengetahuan dosen pada toolbox fuzzy}

Pada toolbox Fuzzy dibuat variabel input Pendidikan dan Pengetahuan dosen dengan membership function Membangun Sistem Pendukung Keputusan untuk Menentukan Dosen yakni cukup, baik, dan sangat baik dalam range 100 Membership function cukup dengan params 020 40, baik dengan params 4060 70, dan sangat baik 7080100 . Adapun gambar tampilan prosesnya seperti berikut ini :

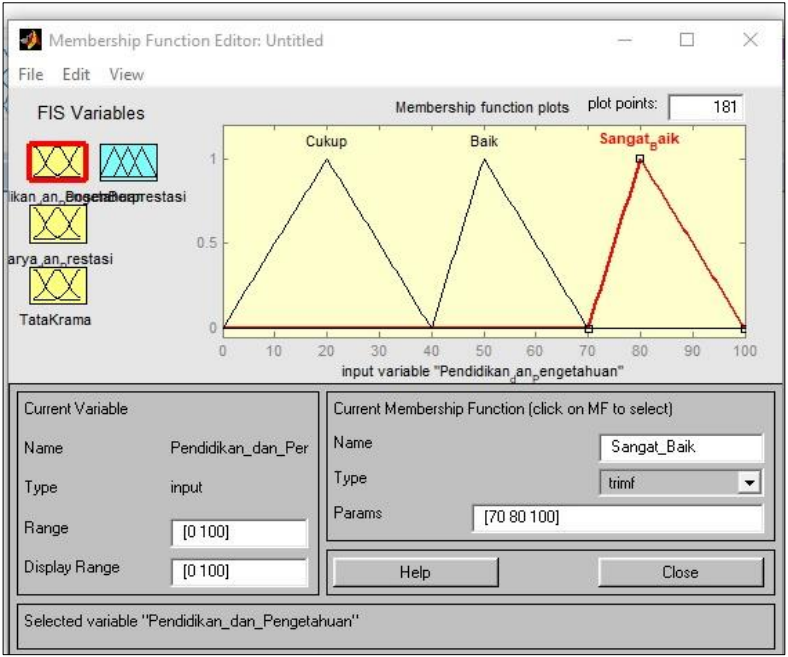

Gambar 3. Tampilan Pembuatan Variabel Input Pendidikan dan Pengetahuan dosen pada toolbox fuzzy

\section{Proses Pembuatan Variabel Output Dosen Berprestasi pada toolbox fuzzy}

Pada toolbox Fuzzy dibuat variabel Output Dosen Berprestasi dengan membership function yakni satu, dua, dan tiga dalam range 100 .

Membership function satu dengan params 020 45, dua dengan params 1050 90, dan sangat baik 7585100 . Adapun gambar tampilan prosesnya seperti berikut ini :

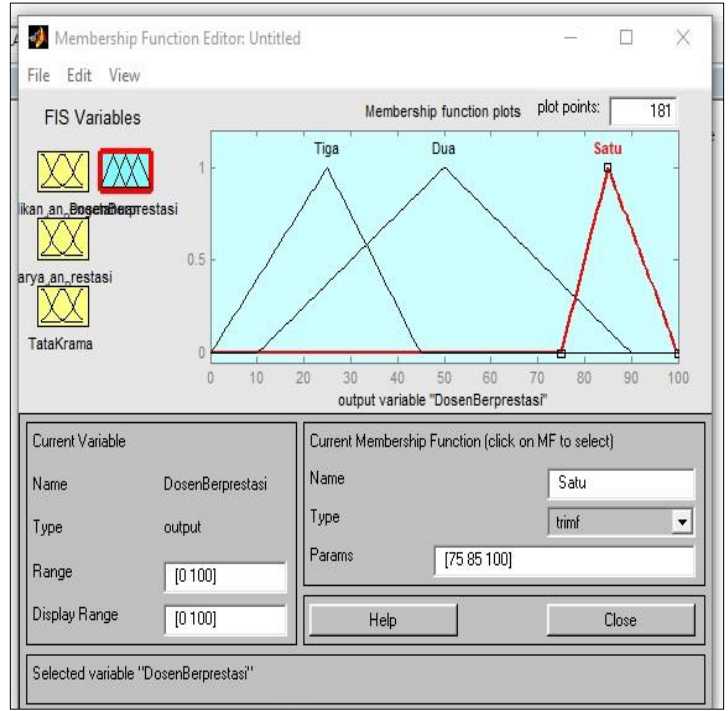

Gambar 4. Tampilan Pembuatan Variabel Output Dosen Berprestasi pada toolbox fuzzy 
E. Proses Pembuatan Rule untuk menentukan Dosen Berprestasi pada toolbox fuzzy

Pada pembuatan rule harus sesuai dengan aturan atau regulasi yang ada dalam menentukan dosen berprestasi satu, dua atau tiga di Prodi Teknik Informatika Universitas Dehasen Bengkulu. Adapun rulenya dan gambar pembuatannya pada toolbox fuzzy sebagai berikut :

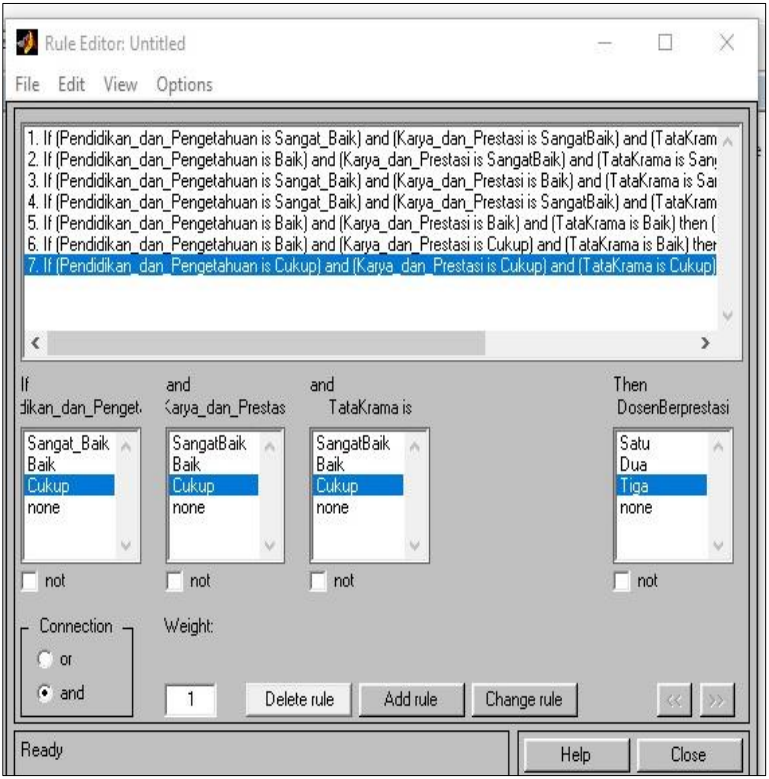

Gambar 5. Tampilan Pembuatan Rule untuk menentukan Dosen Berprestasi pada toolbox fuzzy

\section{F. Proses menentukan Dosen Berprestasi pada toolbox}

\section{fuzzy dengan View Rule}

Untuk menentukan dosen berprestasi satu, dua atau tiga pada toolbox fuzzy yakni dengan memilih view rule dan kita isi nilainya sesuai dengan penilaian secara objektif oleh tim penilai yang sudah diberikan mandat oleh Rektor Universitas Dehasen Bengkulu. Adapun gambar proses menentukan Dosen Berprestasi pada toolbox fuzzy menggunakan metode Fuzzy Mamdani dengan memilih View Rule adalah sebagai berikut :

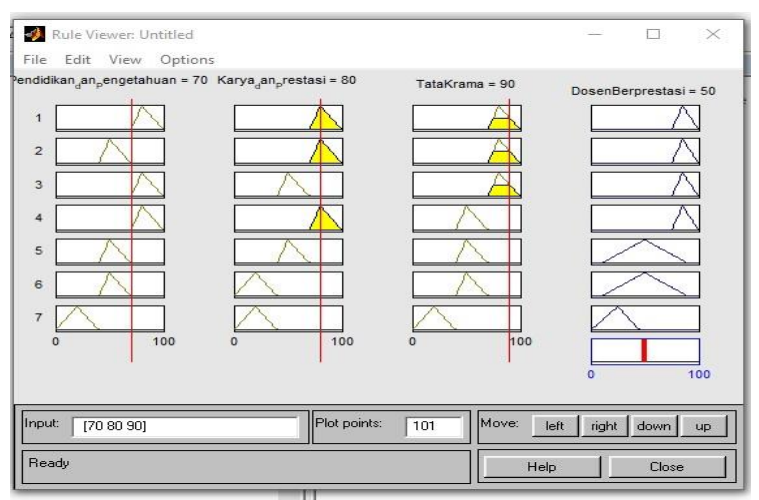

Gambar 8. Tampilan Proses menentukan Dosen Berprestasi pada toolbox fuzzy dengan View Rule

Dari hasil diatas dimasukkan nilai Pendidikan dan Pengetahuan dosen adalah 70, nilai Karya dan Prestasi Dosen adalah 80 dan nilai Tata Krama dosen adalah 90, ternyata oleh aplikasi yang dibuat menghasilkan nilai outputnya adalah 50 yang masuk dalam kategori dosen berprestasi dua artinya dosen tersebut masuk juara kedua dalam ajang Pemilihan dosen berprestasi tingkat Prodi Teknik Informatika Universitas Dehasen Bengkulu.

\section{G. Pengujian Sistem}

Pengujian dimaksudkan untuk menguji apakah system yang telah dibuat akan menemui kendala-kendala atau perbaikan-perbaikan sehingga pengembangan sistemnya akan sesuai dengan harapan dan keinginan ditempat penulis melakukan penelitian. Pengujian system meliputi On going Evaluation dan Alpha Testing.

On going Evaluation : melakukan pengujian system pada aplikasi Matlab 6.0 namun tetap sesuai dengan standar operasional pada sebuah system informasi. Hal ini dimaksudkan untuk menilai apakah system yang penulis bangun sudah beroparasi dengan maksimal sesuai dengan harapan.

Alpa Testing: memperlihatkan hasil system yang telah dibangun kepada pihak-pihak yang berwenang dalam hal ini pihak Fakultas Ilmu Komputer Universitas Dehasen Bengkulu serta dengan orang-orang Ahli dibidangnya yang ada di Fakultas Ilmu Komputer Universitas Dehasen Bengkulu

\section{H. Hasil Pengujian}

Hasil Pengujian yang penulis dapatkan ini adalah hasil dari para responden yang telah mengisi formulir kuisioner terhadap pembuatan Aplikasi Sistem Pendukung Keputusan dalam menentukan dosen berprestasi di Prodi Teknik Informatika, Fakultas Ilmu Komputer, Universitas Dehasen Bengkulu, adapun responden yang ikut serta dalam pengisian formulir adalah para mahasiswa Prodi Teknik Informatika, Fakultas Ilmu Komputer, Universitas Dehasen Bengkulu

Komposisi kuisioner yang penulis lakukan pada penelitian ini adalah dengan melibatkan 10 responden 
dengan 5 buah pertanyaan. Hasil pengujian menggunakan kusioner menunjukkan hasil sebagai berikut.

1. Aplikasi Sistem Pendukung Keputusan dalam menentukan dosen berprestasi di Prodi Teknik Informatika yang dibangun sangat diperlukan oleh civitas akademika Fakultas Ilmu Komputer Universitas Dehasen Bengkulu

2. Aplikasi Sistem Pendukung Keputusan dalam menentukan dosen berprestasi di Prodi Teknik Informatika yang dibangun sangat mudah dioperasikan oleh user

3. Aplikasi Sistem Pendukung Keputusan dalam menentukan dosen berprestasi di Prodi Teknik Informatika yang penulis bangun dirasa sangat mudah ketika user menginput data

4. Aplikasi Sistem Pendukung Keputusan dalam menentukan dosen berprestasi di Prodi Teknik Informatika yang penulis bangun ini telah sesuai dengan harapan para mahasiswa dan dosen Fakultas Ilmu Komputer Universitas Dehasen Bengkulu

5. Aplikasi Sistem Pendukung Keputusan dalam menentukan dosen berprestasi di Prodi Teknik Informatika yang penulis bangun sangat bermanfaat karena sangat membantu dalam program pemberian reward kepada para dosen yang berprestasi

\section{KESIMPULAN}

Penerapan Metode Fuzzy Mamdani pada aplikasi Matlab 6.0 telah berhasil melakukan serangkaian tahapan yang diperlukan dan dapat menentukan dosen yang berprestasi, sehingga membantu pihak Rektorat Universitas Dehasen Bengkulu dalam pengambilan Keputusan terkait penentuan dosen berprestasi di Prodi Teknik Informatika Unived Bengkulu.

Diharapkan kepada pihak manajemen kampus dapat mengembangkan strategi baru untuk kedepannya dalam cara menentukan Dosen yang Berprestasi di Universitas Dehasen Bengkulu.

\section{DAFTAR PUSTAKA}

[1] Ade Sanjaya, 2015, Landasan Teori, http://www.landasanteori.com/2015/09/pengertian-dosen-definisiciri menurut.html diakses tanggal 11 Juli 2018

[2] Firmansyah, 2007, Dasar-dasar Pemrograman Matlab, http://ilmukomputer.org/wp-content/uploads/2007/08/firmandasarmatlab diakses tanggal 12 Juli 2018

[3] Kemenristek Dikti, 2017, Buku Pedoman Pemilihan Dosen Berprestasi Kategori Sains dan Sosial Humaniora tahun Anggaran 2017

[4] E-Library Unikom, 2018 elib.unikom.ac.id/files/disk1/...jbptunikompp-gdl-s1-2004franskurni-501-BAB+II.d diakses tanggal 14 Juli 2018

[5] Universitas Gunadarma, 2018 , http://betty yudha.staff.gunadarma.ac.id/Downloads/files/14881/BA B+5+SISTEM+PENDUKUNG+KEPUTUSAN.doc diakses tanggal 14 Juli 2018 